\title{
Publisher's Note: Compact 810 kA linear transformer driver cavity [Phys. Rev. ST Accel. Beams 14, 040401 (2011)]
}

\author{
J. R. Woodworth, W. E. Fowler, B. S. Stoltzfus, W. A. Stygar, M. E. Sceiford, M. G. Mazarakis, H. D. Anderson, \\ M. J. Harden, J. R. Blickem, R. White, and A. A. Kim \\ (Received 15 April 2011; published 2 May 2011) \\ DOI: $10.1103 /$ PhysRevSTAB.14.059901 \\ PACS numbers: $84.30 . \mathrm{Ng}, 84.70 .+\mathrm{p}, 99.10 . \mathrm{Fg}$
}

This paper was published online on 14 April 2011 with a formatting error in the title. The title should read as "Compact 810 kA linear transformer driver cavity". The title has been corrected as of 19 April 2011. 